\title{
The Impact Of Globalization On The Performance Of Commercial Banks In Nigeria: A Long -Run Equilibrium Analysis
}

\author{
Sunday Ukeje Okanta Ph.D \\ Department of Banking \& Finance \\ Abia State University, Uturu Nigeria \\ Ben Ogbonna Ph.D \\ Department of Economics \\ Abia State University, Uturu Nigeria
}

\begin{abstract}
The research examined the effects of globalization on the performance of Nigerian Commercial banks between 1986 and 2015. Specifically, the research accomplished this task using proxies such as foreign private investment policy, foreign trade policy and exchange rate policy to represent globalization, and using profits before taxes as a proxy for commercial banks' performance. The research employed panel data econometrics in a pooled regression, utilizing autoregressive (dynamic) models in which time series observations were estimated. Tests of model adequacy and normality of residuals, including the test of heteroskedasticity were conducted. The $t$ and $F$ statistics, Durbin-Watson and Breusch-Godfrey tests for the overall significance of the estimated regression and serial autocorrelation first-order were also conducted. Variance decomposition test of the banks' profits before taxes was carried out to establish (for the next 10-year period) the short-run equilibrium swings of the banks' future performance shocks and the ability to recover from the shocks. The results of econometric regression analyses confirmed the following: The autoregressive models were adequate (i.e. they were stable); that is, the model variables and residuals were normally distributed and equally spread (homoscedasticity).There were no first-order serial autocorrelation, a confirmation of the overall significance and non-spuriosity of the findings of the research. In all, foreign private investment and exchange rates had positive and significant effects on the current profits before taxes of commercial banks in Nigeria. However, foreign trade policies had less positive and significant effects on bank performance in Nigeria in the past 30 years; and the 10-year period variance decomposition of the variables showed that the banks would face their own short-run shocks $100 \%$ in the first- year period and recover at zero percent in the same year. However, they would face $42.4 \%$ of such a shock and recover about $58 \%$ of it in the $10^{\text {th }}$ year. The research recommended greater integration of banks in Nigeria to the global community for greater business earnings.
\end{abstract}

\section{INTRODUCTION}

Recently, there has been a lot of clamour toward making the world a great village. Also, there have been intense efforts to make the world a global charity. For instance, in the field of technology the world has become a global village due to the invention of communication and information technology. You cannot imagine where someone in Nigeria sends a message to another in Germany or United State of America and receives instant respond. You cannot imagine where a football match being played in one country can be instantly witnessed by over three hundred million people, scattered all over the world, through electronic means. You cannot imagine how goods produced in a particular country can be consumed in far away countries. This is the same with the banking industry. Imagine where someone in one continent transacts with another in a different continent and makes payment through electronic means, irrevocable letters of bill of lading, etc. 
The banking system has become the bridge between one country and another with respect to international trade, foreign investments and exchange rates .The direction of the volume of these trades, investments and exchange rate movements can have profound impact on the banking activities in an open economy. Globalization - a greater integration of trade, investments, politics, cultures, etc. across international borders - can significantly affect a country's banking system. It is this relationship between globalization and the banking system of Nigeria that this paper investigated.

\section{Statement of the Problem}

Research has shown that a banking system's soundness and stability significantly place it in a better stead to gain from business. Such a steady state is believed to insulate the banking system against distress, contagious and moral hazard. It determines the efficiency and productivity of the banking system

Research has it that the capital base of the largest bank in Nigeria is USD240 million while the smallest bank in Malaysia has USD526 million capital base. An average bank in Nigeria operates with less than USD 10 million (Akinlabi, et al,2013). This situation has relegated Nigerian banks to the background in the world financial markets. Most banks, in response to the real sector, have continued to engage in unprofessional and unethical conducts. Most have shifted from core banking activities to money laundering, and market targeting for all levels of workforce (requiring pressure) to win deposits. Unethical marketing practices have become the norm for many banks. This inhibits the banks' ability to meet the demands of world financial markets.

There has been a liquidity and insolvency problems faced by banks, which are evidenced by negative capital base, poor adequacy ratios, poor liquidity ratio and poor shareholders funds. Profits are being eroded by rising operating costs. These problems tend to contribute to the banks' inability to meet certain degrees of soundness needed for the sustenance of the globalized banking operations. Curtailment of excessive risk taking by Nigerian banks, as a policy in the banking industry when compared with the global banking standards, has been thrown overboard. As the competitive struggle for survival with inadequate capital base intensified, marginal banks resorted to excessive risk taking and constant breaking of regulating rules. Insider dealing, which is the use of information and other resources obtained through the bank to effect transactions that benefit others related to self, has also blossomed, resulting to preferential credit granting without collateral. These emerging problems have necessitated the course of the study which aims at determining the extent to which global participation of Nigerian commercial banks contribute to the banks' performance.

\section{Objectives of the Study}

Specifically, the objectives of this paper are:

1. To identify the various ways by which globalization could influence e the banking sectors' performance.

2. To explore theoretical issues in bank performance and globalization.

3. To establish statistical relationships between Nigerian commercial banks' performance and globalization.

\section{Research Questions}

The following research questions are raised:

1. To what extent does foreign direct investment (FDI) inflow affect the efficiency and productivity growth of Nigerian commercial banks?

2. To what extent has foreign exchange rate volatility affected the efficiency and 
productivity growth of Nigerian commercial banks?

3. How does foreign trade affect the efficiency and productivity growth of Nigerian commercial banks?

\section{Research Hypotheses}

1. Ho1: There is no significant and positive relationship between Nigerian commercial banks' performance and inflows of foreign direct investment in the last thirty years.

2. $\mathrm{Ho}_{2}$ : There is no significant and positive relationship between Nigerian commercial banks' performance and foreign exchange rate movements in the last thirty years.

3. $\mathrm{Ho}_{3}$ : There is no significant and positive relationship between Nigerian commercial banks' performance and foreign trade in the last thirty years.

\section{Significance of the Study}

For continuous existence and progress in service delivery, banks need to always meet the required standard in the global setting. One of the significance of this study is that it serves as a reading research document that provides a better understanding of bank-global transfer relationships. The study is of immense values to the students of economics and business because it will remain a source of data for them and others who may wish to carry out further researches on similar research problems. The research will also be a source of inspiration to monetary authorities to boost their policy strategies.

\section{Scope and Limitations of the Study}

For the purpose of this study, the researchers restricted the scope to the impact of globalization on the Nigerian banking industry. The main focus is on the application of the globalization indices to service delivery of commercial banks in Nigeria to determine their aggregate performance in the last thirty years (1986-2015). The study is limited to a specificcountry analysis in Africa. Nigeria was chosen because of its outstanding position in Africa as one of the emerging economies with strong and virile global participations and multilateral agreements. Again, the study is limited to the recent econometric techniques which establish interactive long-run equilibrium state of a given model.

\section{LITERATURE REVIEW}

Considering the importance of the advent of globalization in the banking sector, especially commercial banks, researchers around the world have conducted different studies with varying levels of interest and details. Though much have been written regarding the benefits and downsides of globalization, there are few concrete, empirical evidences and discussions on financial globalization for the financial industry especially the banking industry. Few available researches in Nigeria focused on effects of globalization on financial markets and financial sector development (i.e. see Baba et al., 2006). Financial globalization has grown in size and scale in Nigeria.

\section{The evolution of Globalization}

Egware (2009) traced the history of globalization back to the post World War II phenomenon. Globalization may in many ways be viewed as a resumption of a trend observed in the world economy in the $19^{\text {th }}$ century. The process observed before 1914 could hardly be called "globalization" however, since most regions of the world did not participate and because the speed of transmission and communication was much less feasible than it is today, to organize markets, or to operate firms at the global level. Furthermore, international financial markets today are characterized by much larger gross flows, with a much larger variety of financial instruments being trader across borders. The period from the mid $19^{\text {th }}$ century to World War I 
exhibited relatively rapid growth in world trade, as the expansion of exports significantly outpaced that of real output. The share of exports in world output reached a peak in 1913. Growth in trade occurred partly as a consequent of reduced tariff and greatly reduced transportation costs reflecting the proliferation of railroads and steamships (Akinlabi, Osamor, 2013).

The process of trade liberation in Europe began with Britain's unilateral movement to free trade with the abolition of the Corn Laws of 1846. It spreads to other countries with the Cobden Hevallier Treaty of 1860 between Britain and France. The Treaty in addition to reducing French tariff rates, incorporated a Most-Favoured-Nation (MFN) clause in which each contradicting party agreed to extend to the other any reduction in tariff rates are introduced vis-a vis a third party. Due to the reduction of tariff only to the Britain, it gave other trading partners an incentive to sign similar treaties with it. Within the next two decades, virtually all of Europe reduced tariffs in a series of bilateral agreements with MFN clauses (Eqware,2009). The fact was that the non-tariff barriers were of secondary importance and foreign exchange transactions were not controlled under the classical gold standard that prevailed before 1914 . The network of bilateral commercial treaties constituted a liberal multi-lateral trade regime. However, the system had two major shortcomings, which are: it did not guarantee tariff reductions and the treaties were subject to renegotiation upon expiration. These two defects were rectified in the multilateral arrangement instituted after World War II.

The first World War led to a series of quantitative restrictions on trade by the belligerents. After the War, many countries reduced their restrictions but substituted tariffs in 1929 following an increase of twenty-three percent (23\%) on import duties by the United States in mid 1930. Most countries retaliated, while some countries instituted quantitative restrictions and other trade barriers in an attempt to stimulate their economies. The deflation of the 1930's caused some countries including the United Kingdom and the United States to abandon the gold standard, devalued their countries and pursed expansionary polices. On the other hand, the gold bloc (France, Italy, Belgium, the Netherlands, and Switzerland) staged on gold, but raised tariffs. A third group (Germany, Australia, and the central European countries) used exchange controls to create a series of bilateral trade agreements. By the mid 1930's tariff protection in US was reduced following the Reciprocal Trade Agreement Act of 1934, under which the United States negotiated a series of bilateral agreements. At the end of the Second World War, the general Agreement on Tariffs and Trade (GATT) was created by the international community along with the IMF and the World Bank. Based On the principles $\mathrm{f}$ multilateral cooperation, the GATT had a mandate to roll back tariffs from their pre-war levels and to continue reducing the tariffs by a least 35 percent. Successive Rounds in the 1950's and 1960's (the kenedy Round) and the 1970s (Tokyo Rounds) and the Uruguay Round have to a large extent eliminated tariffs on manufacture red goods. The World Trade Organization (WTO), which succeeded GATT in 1994, is currently engaged in reducing non-tariff barriers and protection, including the areas not covered by the GATT (Akinlabi, Osamor, 2013).

\section{The Evolution of the Nigerian Banking Sector}

The banking operation began in Nigeria in 1892 under the control of the expatriates and by 1945, some Nigerians and Africans had established their own banks. The first era of consolidation ever recorded in Nigeria banking industry was between 1959 and 1969. This was occasioned by bank failures during 1953-1959 due to liquidity problems of banks. Banks, then, did not have enough liquid assets to meet customers demand. There was no wellorganized financial system with enough financial instruments to invest in. Hence, banks merely invested in real assets which could not be easily realized to cash without loss of value in time of need. This prompted the Federal Government then, backed by the World Bank Report, to 
institute the Loyne's Commission on September 1958. The outcome was the promulgation of the Ordinance Act of 1958, which established the Central Bank of Nigerian (CBN).The year 1959 was remarkable in the Nigerian banking history not only because of the establishment of the Central Bank of Nigeria(CBN), but that the Treasury Bill Ordinance was enacted which led to the issuance of Nigeria's first treasury bills in April, 1960.

The period (1959-1969) marked the establishment of formal money, capital markets and portfolio management in Nigeria. In addition, the Company's Act of 1968 was enacted. This period could be said to be the genesis of serious banking regulations in Nigeria. With the CBN in operation, the minimum paid-up capital was set at $\$ 400,000$ (USD\$480,000) in 1958. By January 2001, the banking sector was fully deregulated with the adoption of universal banking system in Nigeria which merged merchant bank operations with the commercial bank system, preparatory towards consolidation programme in 2004.

In the 1990s proliferation of banks which also resulted in the failure of many of them, led to another recapitalization exercise that saw banks' capital being increased to $\$ 500$ million (USD \$5.88) and subsequently N2billion (USD\$0.0166billion) in 2004 with the institution of a 13-point reform agenda aimed at addressing the fragile nature of the banking system, stopping the boom-burst cycle that characterized the sector and evolving a banking system that would not only serve the Nigerian economy, but also the West African regional economies. The agenda by the monetary authorities is also to consolidate the Nigerian banks and to make them capable of playing in international financial system. However, there appears to be divergence between the state of the banking industry in Nigeria and the vision of the government and regulatory authorities for the industry. This, in the main, was the reason for the policy of mandatory consolidation, which was not open to dialogue and its components also seemed cast in concrete.

In terms of number of banks and minimum paid-up-capital, between 1952 and 1978, the banking sector recorded forty-five (45) banks with varying minimum paid-up-capital for merchant and commercial banks. The number of banks increased to fifty-four (54) between 1976 and 1987. The number of banks rose to one hundred and twelve (112) between 1988 and 1996 with substantial varying increase in the minimum capital. The number of banks dropped to one hundred and ten (110) with another in minimum paid-up capital and finally dropped to twenty-five (25) in 2005 with a big increase in minimum paid-up capital from N2billion (USD\$0.0166billion) in January 2004 to N25billion (USD\$0.2billion) in July 2004 (Somoye, 2008). After the consolidation, the number of banks later reduced to twenty-three (23), due to the merger of some banks. These banks are saddled with the following functions among others: acceptance of deposits from customers; provision of credit facilities in form of loan and overdraft; management of customer's portfolio of investment and provision of investment advice.

\section{Prior Studies on the Impact of Globalisation and Performance of Banks}

Goyal (2006) carried out a study on the impact of globalization on developing countries with special reference to India, he discovered that globalization in India had a favourable impact on the overall growth rate of the economy. The growth rate was as low as 3\% in 1970, but almost double to $5.9 \%$ in the eighties as a result of globalization. Studies have proven that globalization has impacted different economy in different ways.

The efficiency and performance of commercial banks have been studied extensively over the last several decades. For instance, Ferrier and Lovell (1990), Elyasiani and Mehdian (1992), 
Grabowski et al. (1993) and Alam (2001), among others, use the Data Envelope Analysis (DEA) approach to assess the production performance of U.S. commercial banks relative to several best practiced frontiers. The empirical findings of these studies suggest that the overall efficiency of the U.S. banking industry ranged from $65 \%$ to $90 \%$ in the 1980 s and 1990 s. The performance of banks operating in countries outside the U.S. has also been studied extensively. For example, Berg et al. (1992) and Berger et al. (1993) evaluate the efficiency and productivity growth of banking industries in Nordic countries, and conclude that Swedish banks are the most efficient, followed by Norwegian banks and then Finnish banks. Pastor et al. (1997) analyze and compare the efficiency of the banking industries in Europe and U.S. These authors report that banks operating in France, Spain and Belgium are the most efficient banks in their samples, whereas banks operating in the U.K., Austria and Germany illustrate the lowest efficiency levels.

Lozano-Vivas et al. (2002) examine the performance of a sample of banks in ten European countries, and conclude that country-specific environmental conditions exert a significant influence on the performance of each country's banking industry. Most recently, Casu et al. (2004) employ both parametric and non-parametric approaches to estimate productivity change in European banking systems from 1994 to 2000. They find that productivity growth was highest for Spanish and Italian banks, and more modest for France, German and British banks. There are a limited number of papers in which the authors have studied the efficiency of banks in Asia (see for instance, Fukuyama (1995) for Japan, Yeh (1996) for Taiwan, Leightner and Lovell (1998) for Thailand, Gilbert and Wilson (1998) for Korea, and Lim and Chu (1998) and Rezvanian and Mehdian (2002) for Singapore). The results of most of these studies show that, in general, depository institutions have an average efficiency of approximately $77 \%$.

\section{Banking And Globalization}

The banking industry gradually spread outward from the classical civilizations of Greece and Rome into Northern and Western Europe (Rose, 1999). The development of new overland trade routes and improvements in navigation in the $15^{\text {th }}, 16^{\text {th }}$ and $17^{\text {th }}$ centuries gradually shifted the centre of world commerce from the Mediterranean region to Europe and the British Isles where banking became a leading industry. During this period were planted seeds of the Industrial Revolution, which demanded a well - developed financial system because of the more need to make payments and credits. Banks that could deliver on these needs grow rapidly.

When colonies were established in North and South America, old World banking practices were transferred to the New World. Colonialists dealt primarily with established banks in the countries for which they had come.

Banking presence on the World Wide Web has exploded into great prominence in the most recent era, with thousands of banks displaying their own individual web sites and well over 100 sites tracking industry trends. Banks have rushed onto globalization in greater numbers making it easier all the time to evaluate this fascinating industry's globalized performance space.

\section{Preamble}

\section{RESEARCH METHODOLOGY}

The purpose of this section is to present the models employed in conducting the research. Specifically, the section discusses the instruments used, the research design, area of study, population, etc. 


\section{Research Design}

Design means the structure of investigation aimed at identifying variables and their relationships with one another. According to Abosede and Déji (2001), this is to enable the researchers test hypothesis or answer research questions. It is an outline of a scheme that serves as a useful guide to the researcher in his effort to generate data for this study. A de facto co-relational research design is adopted in this study.

\section{Area of Study}

The area of the study centres on the impact of globalization on the Performance of the banking industry. It tries to study the implications and challenges posed by globalization on the banking industry. The area of the study is strictly on commercial banking.

\section{Population for the Study}

Population refers to the totality of the individual items whether of peoples or things that are to be investigated in a given problem or situation. The population of this study is made up of the aggregate commercial banks operating in Nigeria.

\section{Method of Data Collection}

There are basically two methods in data collection for any study. These are: the primary data and secondary data. In this study, a wholesome secondary data was adopted.

\section{Model Specification}

Using the panel data regression model, the researchers state as follows:

$$
Y_{t}=a_{0}+a_{1} X_{1 t}+a_{2} X_{2 t}+a_{3} X_{3 t}+U_{t}
$$

Where,

$\mathrm{t}=\mathrm{t}_{\text {th }}$ time period

$\mathrm{U}_{\mathrm{t}}=$ the error term

$a_{1}, a_{2}, a_{3}=$ the coefficients of $X_{i}$

$\mathrm{a}_{0}=$ fixed effect or the intercept.

Taking account of "individuality" of each bank and its cross sectional effects, the researchers vary the intercept for each, but still keep the slope coefficient constant.

Therefore, the model can be shown as:

$$
Y_{i t}=a_{0}+a_{1} X_{1 i t}+a_{2} X_{2 i t}+a_{3} X_{3 i t}+U_{i t}
$$

Where;

i stands for the ith cross sectional unit

$\mathrm{X}_{1 \mathrm{i}}$ are random variables

$\mathrm{U}=$ the error term

\section{Data Analysis Technique}

The study employed the analytical method using data from secondary sources. The analysis enables us to either accept our null hypothesis, $\mathrm{H}_{0}$, or accept the alternative hypothesis, $\mathrm{H}_{\mathrm{A}}$. Essentially, the study aims at evolving an empirical analysis of the impact of globalization on performance of Nigerian commercial banks. The E-view Computer software was used to analyze the data, while Panel Data Regression model was used to capture the cross-sectional data and time series analysis of aggregate commercial bank performance in Nigeria. 


\section{Data Presentation}

\section{DATA PRESENTATION , ANALYSIS AND INTERPRETATION.}

The impact of globalization is measured by the indices of globalization, such as cumulative foreign private investment (FPI), foreign trade (FTR) and exchange rate (FXR). The chosen index of commercial bank performance is profit before tax (PBT). The indices are shown in Appendix Table 4.1. They were sourced from CBN Statistical Bulletins and Annual Statements of Account (various years).

Cumulative foreign private investments are foreign capital inflow from one country to another. Foreign trade is the net exports of goods and services across international borders. Exchange rate is the amount of one currency that buys another currency (In this case, the amount of Nigeria's Naira that buys one US dollar on average).

\section{Data Analysis}

\section{Test of Model Adequacy and Normality of Residuals}

Table 4.2 in the Appendix shows the Jarque-Bera (JB) test of normality which is used to find out whether the OLS residuals follow the normal distribution. This is done to satisfy the normality assumption requirements of the ' $\mathrm{t}$ ' and ' $\mathrm{F}$ ' stats. Since the $\mathrm{p}$-value of JB stats are sufficiently low (i.e. p- value $<0.05$ ) JB stats are very different from zero, we reject the $\mathrm{H}_{\mathrm{o}}$ that the error terms are normally distributed. But we keep in mind that the sample size of 30 observations may be large enough to estimate the OLS coefficients. The graphical representation of the test of normality of residuals is shown in figure 4.2 . We reject the null hypothesis that the residuals are normally distributed.

\section{Heteroscedasticity Test}

This test is one of fulfilling a major assumption of the classical linear regression model which specifies that the variance of the error, or disturbance term is the same regardless of the value of the explanatory variable (i.e. var [ui] $=\mathrm{E}[\mathrm{ui} / \mathrm{Xi}]^{2}$ ). This means that the variance of ui for each explanatory variable must be some positive constant number, i.e. they are equally (homo) spread or of equal variance (homoscedasticity or constance variance). Where the opposite of (var [ui] $=\mathrm{E}[\mathrm{ui} / \mathrm{xi}]^{2}$ ) occurs, the situation is known as heteroscedasticity or unequal spread of variance (see table 4.3$)$. Since the prob. of $F$ stats.is greater than $0.05(0.9994>0.05)$, we conclude that there is no heteroscedasticity or unequal spread of variance, hence the assurance of the stability of the regression model.

\section{Estimated Distributed - lag Model}

The autoregressive model (or dynamic model) as shown in Table 4.4 includes lagged values of the dependent variable among its explanatory variables. It shows the time series path of the dependent variable in relation to its past values. Table 4.3 is an estimated distributed-lag model -a sequential procedural model in which we first regress $Y_{t}$ on $Y_{t-1}$, then regress $Y_{t}$ on $X_{t}$ and $X_{t-1}, X_{t-2}$, etc, and stop when the regression coefficients of the lagged variables start becoming statistically insignificant. The rise in globalization is spread or distributed on commercial banks' performance over a period of 30 years, and it is reflected in the short-run long-run relationships. We adopted distributed lag model because of the individual bank domestic and institutional and contractual obligations and changes in global technologies.

From Table 4.4, we find that the recent past two years rise in bank performance significantly affect the current performance. The estimated distributed-lag model obeyed the Koyck approach where the coefficients are all of the same sign and they decline geometrically, with the rate of decline, $\lambda$, such that $0<\lambda<1$ (Gujarati, 2013). In this case, PBT(-2) significantly 
affects the current bank performance but of less degree of impact.

In the table, one year lagged FPI significantly affects the current performance. Also, one year lagged FXR significantly affects the current bank performance. From the analysis, one year lagged PBT, FPI and FXR significantly influence current commercial banks' performance. At the fourth lagged model, FTR does not significantly influence the current performance of commercial banks in Nigeria.

$\mathrm{R}^{2}$, which measures the overall goodness of fit of the regression model is 0.94486 (about $94 \%$ ). It tells that $94 \%$ of the variation in the bank performance (regressed) is explained by the explanatory variables (regressors). Allowing for $n-k$ degree of freedom (DF), the adjusted $\mathrm{R}^{2}$, a supplementary measure of goodness of fit, as expected,is 0.846829 (about 85\%) which is less than $\mathrm{R}^{2}(94 \%)$. The $\mathrm{F}$ test, a measure of the overall significance of the estimated regression and a test of significance of $\mathrm{R}^{2}$ is 9.638516 , is significant at about $5 \%$ level, since the $\mathrm{p}$-value is actually 0.000816 , which is less than 0.05 . Therefore, we can reject the null hypothesis that the regressors, FPI and FXR have no impact on commercial banks' performance.

The Durbin-Watson, d, test reported along with the summary measures in table 4.3 is used not only to necessarily indicate autocorrelation but to indicate omission of relevant variables in a model. The d-value of 2.075837 suggests that there is no (first-order) autocorrelation in our model. Thus, there is a built-in bias against discovering (first-order) autocorrelation in VAR models.

According to Fomby, et al (1984), the fact that VAR models have built-in biases against discovering (first-order) autocorrelation, and that such an assumption that d-value is not applicable to a regression model that includes lagged value(s) of the dependent variable (regressand), it does not mean that VAR models do not suffer from the autocorrelation problems. As a matter of fact, d-value tests of such VAR models are usually weak. The more powerful Breusch-Godfrey (BG) test (LM test) is employed here (see table 4.5). This is a general test of autocorrelation. The BG test or LM test allows for non stochastic regressors such as the lagged values of the regressand and higher-order autoregressive schemes, such as AR (1), AR (2), etc, and simple or higher-order moving averages of white noise error terms, such as E. Each of the BG test value or p-value of the lag length of AR (1) - AR (4) coefficients being less than one (i.e. $p \neq 1$ ), shows that there is no first order autocorrelation. The d-value of 2.000503 gives a better, perfect non-serial first-order autocorrelation seen in our model.

\section{Forecasting}

Assuming that the features of our model are constant through time, and particularly over the future 10-year period, and that the variables are stationary or stable, we forecast commercial banks performances by interpreting their own savings of shock for this extended period, using variance decomposition of PBT. In period 1, the forecast due to own shock emanating from banks performance is $100 \%$. In period 2, the forecast is $80.4 \%$ and it declines to $42.4 \%$ in the $10^{\text {th }}$ period (see Table 4.6 ).

\section{SUMMARY, CONCLUSION AND RECOMMENDATIONS}

\section{Summary of Findings}

This study examined the long-run impact of globalization on performance of Nigerian commercial banks between 1986 and 2015. It specifically exermined the long-run effects of policies of foreign private investment, foreign trade and exchange rate on performance of Nigerian banks. The study utilized panel data econometrics in autoregressive models (dynamic 
models). Jarque-Bera (JB) and residuals normality tests were used to determine the adequacy (stability) of the models. Heterosked asticity test (Breusch-Pagan-Godfrey test) was also carried out to determine the constancy of variance (homoscedasticity or equal spread of variance). Breusch-Godfrey (GB) serial correlation test or LM test) was used to determine a higher-order serial autocorrelation in the dynamic models. We forecast bank performance by noting its own swings of shocks for an extended 10-year periods, using variance decomposition test.

The estimated models show that the current commercial banks' performance is significantly influenced by its past first and second performances, first and past values of foreign private investment and first and fourth past values of exchange rates. However, there is no significant relationship between commercial banks' current performance and the lagged values of foreign trade in the last 30 years. Our dynamic models maintained the stability criteria and there is an absence of serial autocorrelation in the estimates.

\section{Conclusion}

From the summary of findings, globalization has significant influence on performance of banks in Nigeria. However, the magnitude of the influence of foreign trade on bank performance remains insignificant. This is glaring, as Nigeria has continued to lag behind in global trades, depending wholly on a mono-product international trade (oil).

Globalization is a development that should not be taken likely because it exposes an economy to the world at large. In considering the impact of globalization, it is pertinent to analyze aspects of globalization that are significant in influencing the sector of the economy under discussion. Commercial bank performance is vital to the growth of any economy. Therefore, its strong relationship with the global sector is as well important. Government policies must take these relationships into cognizance.

\section{Recommendations}

Based on the above findings, this research recommends that commercial banks in Nigeria should not relent in their interactions with the global community in doing business in order to increase their foreign earnings. Banks should invest more on global technologies to be able to enjoy a greater percentage of global trades and investments. The researchers further recommend that more banks should embrace international banking in order to increase their foreign participation and earn more profits.

\section{References}

Alam, I.M.S. (2001). A non-parametric approach for assessing productivity dynamics of large US banks. Journal of money, credit and banking, 33:121-39.

Akinlabi, H., Osamar V.C. (2013). An empirical analysis of the impact of globalization on the performance of Nigerian commercial banks in post-consolidation period. European journal of business and management, 5(5): $37-$ 40 .

Bada, A.D., Okunoye, A., Eyob, E., Adekoya, A., Omojokun, E.(2006). Globalization and the Nigerian banking industry: efficiency and legitimacy considerations in the adoption of electronic banking (e-banking) services. International journal of management and decision making, 7(5): 494-507.

Berg, S.A., Forsund, R.R., Jansen, E. S. (1992). Malmquist indices of productivity growth during the deregulation of Norwegian banking. Scandinavian journal economics. 94: 211-220.

Berger, A.N., Hunter, W.C., Timme, S.G. (1993). The efficiency of financial institutions: a review and preview of research past, present and future. Journal of banking and finance, 17: 211-228.

Casu, B., Giradone, C., Molyneux, P. (2004).Productivity change in European banking:a comparison of parametric and nonparametric approaches. Journal of banking and finance, 28: 2521-2541. 
Egware, L.E.(2009).International business finance and management. lagos: Concept publications Ltd.

Elyasiani, E., Meldian, S. (1995). The Comparative efficiency performance of small and large US commercial banks in the pre and post deregulation eras. Applied economics, 27: 69-79.

Ferrier, G.D., Lovell, C.A.K. (1990). Measuring Cost Efficiency in banking: econometric and Linear Programming Evidence. Journal of Econometrics, 46:229-245.

Fomby, T.B., Carter, R.H., Johnson, S.R. (1984).Advanced econometric methods.NewYork:Springer verlag in Gujarati D.N. (2013). Basic econometrics, $5^{\text {th }}$ ed.

Fukuyama, H. (1995).Measuring Efficiency and Productivity Growth in Japanese Banking: A Non-parametric Frontier Approach. Applied Financial Economics, 5: 95-107.

Gilbert, R.A., Wilson, P.W. (1998). Effects of Deregulation on the Productivity of Korean Banks. Journal of Economics and Business, 50: 133-155.

Goyal, K.A. (2006). Impact of Globalization on Developing Countries(with special reference to India). International Research Journal of Finance and Economics, Issue 5.

Grabowski, R. Rangan, N., Rezvanian, R. (1993). Organizational forms in banking: An empirical investigation of cost efficiency. Journal of Banking and Finance, 17: 531-538.

Gujarati. D. (2013).Basic econometrics. New York: McGraw-Hill publishing company, 765-899.

Leightner, J.E., Lovell, C.A.K. (1998).The impact of financial liberalization on the performance of the Thai banks.Journal of economics and business, 50:115-131.

Lim, G.H., Chu, S. (1998). Efficiency and returns: an empirical study of six Singapore-listed banks. Asian pacific journal of finance, 1: 191-207.

Lozane-Vivas, A.A., Pastor, J.T., Pastor, J.M.(2002). An efficiency comparison of European banking systems operating under different environmental conditions. Journal of Productivity Analysis,18 59-77.

Pastor, J.M., Perez, F., Quesada, J. (1997). An efficiency analysis in banking firms: An international comparison. European journal of operations research, 98: 395-407.

Rezevanian, R.,Mehdian,S.M.(2002).An examination of cost structure and production performance of commercial banks in Singapore. Journal of banking and finance 26:79-98.

Soludo, C.C. (2007). Central bank and the globalization forces of 21 st century. Abuja: CBN research department. Somoye, R.O.C. (2008).The performances of commercial banks in post-consolidation period in Nigeria: An empirical review. European journal of economics, finance and administrative sciences, Issue 14.

Yeh, Q.J. (1996).The application of data envelopment analysis in conjunction with financial ratios for bank performance evaluation. Journal of operation research society, 47: 980-988. 


\section{APPENDIX I}

Table 4:1 Nigeria: Bank Performance and Globalization Indices

\begin{tabular}{|llllll|}
\hline & YEAR & PBT & CFPI & FT & ER \\
\hline 1 & 1986.00 & 470.000 & 9313.6000 & 3443.9000 & 2.0206 \\
\hline 2 & 1987.00 & 1636.000 & 9993.6000 & 133968.1000 & 4.0179 \\
\hline 3 & 1988.00 & 1335.100 & 11339.2000 & 11435.000 & 4.5367 \\
\hline 4 & 1989.00 & 1118.0000 & 10899.6000 & 307703000 & 7.3916 \\
\hline 5 & 1990.00 & 2473.9000 & 10436.1000 & 70114.9000 & 80378 \\
\hline 6 & 1991.00 & 2210.8000 & 12243.5000 & 44677.9000 & 9.9095 \\
\hline 7 & 1992.00 & 24196.2000 & 20512.7000 & 81000.4000 & 17.2984 \\
\hline 8 & 1993.00 & 35516.6000 & 66787.0000 & 72060.4000 & 22.0511 \\
\hline 9 & 1994.00 & 41588.5000 & 70714.6000 & 61335.9000 & 21.8861 \\
\hline 10 & 1995.00 & 470124000 & 1193916000 & 247177.7000 & 21.8861 \\
\hline 11 & 1996.00 & 52802.3000 & 122600.9000 & 678557.2000 & 21.8861 \\
\hline 12 & 1997.00 & 50460.2000 & 128331.9000 & 409408.4000 & 21.8861 \\
\hline 13 & 1998.00 & 471441000 & 152410.9000 & -18449.4000 & 21.8861 \\
\hline 14 & 1999.00 & 96630.1000 & 154190.4000 & 395972.4000 & 92.6934 \\
\hline 15 & 2000.00 & 132654.3000 & 157508.6000 & 1059203.200 & 102.1052 \\
\hline 16 & 2001.00 & 254151.4000 & 161441.6000 & 7669626000 & 111.9432 \\
\hline 17 & 2002.00 & 2452842000 & 166631.6000 & 382751.9000 & 120.9702 \\
\hline 18 & 2003.00 & 272300.6000 & 178478.6000 & 1215674.700 & 129.3565 \\
\hline 19 & 2004.00 & 186507.3000 & 249220.6000 & 2615736.300 & 1335004 \\
\hline 20 & 2005.00 & 120391.1000 & 3432490.100 & 3832995.800 & 132.1470 \\
\hline 21 & 2006.00 & 88806.4000 & 4007515.200 & 4495928.100 & 128.6516 \\
\hline 22 & 2007.00 & 186407.3000 & 4403765.800 & 4749881.400 & 125.8331 \\
\hline 23 & 2008.00 & 206507.3000 & 6041843.500 & 5438769.700 & 118.5669 \\
\hline 24 & 2009.00 & -1373330.00 & 8111380.900 & 377.3346 .400 & 148.8802 \\
\hline 25 & 2010.00 & 607340.000 & 9088816.400 & 4546102.400 & 150.2980 \\
\hline 26 & 2011.00 & -6710.0000 & 10544633.10 & 4746349.300 & 153.8616 \\
\hline 27 & 2012.00 & 458784.0000 & 11573120.30 & 5218151.500 & 157.4994 \\
\hline 28 & 2013.00484780 .000 & 13511020.00 & 60233131.10 & 157.3112 \\
\hline 29 & 2014.00 & 495680.2000 & 14110341.10 & 65548112.40 & 158.5526 \\
\hline 30 & 2015.00 & 201203.1000 & 91733170.50 & 50343611.10 & 198.6810 \\
\hline & & & & & \\
\hline & Source: CBN Statistical Bulletins and Annual Statements of Accounts (Various Years) \\
\hline & & & & & \\
\hline
\end{tabular}


Table 4:2: Test of Model Adequacy

Date: $08 / 02 / 16$ Time: $19: 36$

Sample: 19862015

\begin{tabular}{|lcccc|}
\hline & FPI & FTR & FXR & PBT \\
\hline \hline Mean & 5945685. & 7372939. & 83.45152 & 98845.74 \\
Median & 159475.1 & 722759.9 & 107.0243 & 70804.35 \\
Maximum & 91733171 & 65548112 & 196.6810 & 607340.0 \\
Minimum & 9313.600 & -18449.40 & 2.020600 & -1373330. \\
Std. Dev. & 16829399 & 17627399 & 64.58400 & 325219.4 \\
Skewness & 4.626787 & 2.671747 & -0.031555 & -2.941366 \\
Kurtosis & 24.09906 & 8.393254 & 1.373182 & 15.40442 \\
& & & & \\
Jarque-Bera & 663.4987 & 72.05016 & 3.313150 & 235.5951 \\
Probability & 0.000000 & 0.000000 & 0.190791 & 0.000000 \\
Sum & $1.78 \mathrm{E}+08$ & $2.21 \mathrm{E}+08$ & 2503.546 & 2965372. \\
Sum Sq. Dev. & $8.21 \mathrm{E}+15$ & $9.01 \mathrm{E}+15$ & 120961.7 & $3.07 \mathrm{E}+12$ \\
Observations & 30 & 30 & 30 & 30 \\
\hline
\end{tabular}

Figures 4:2 Graphical Representation of normality of the residual test
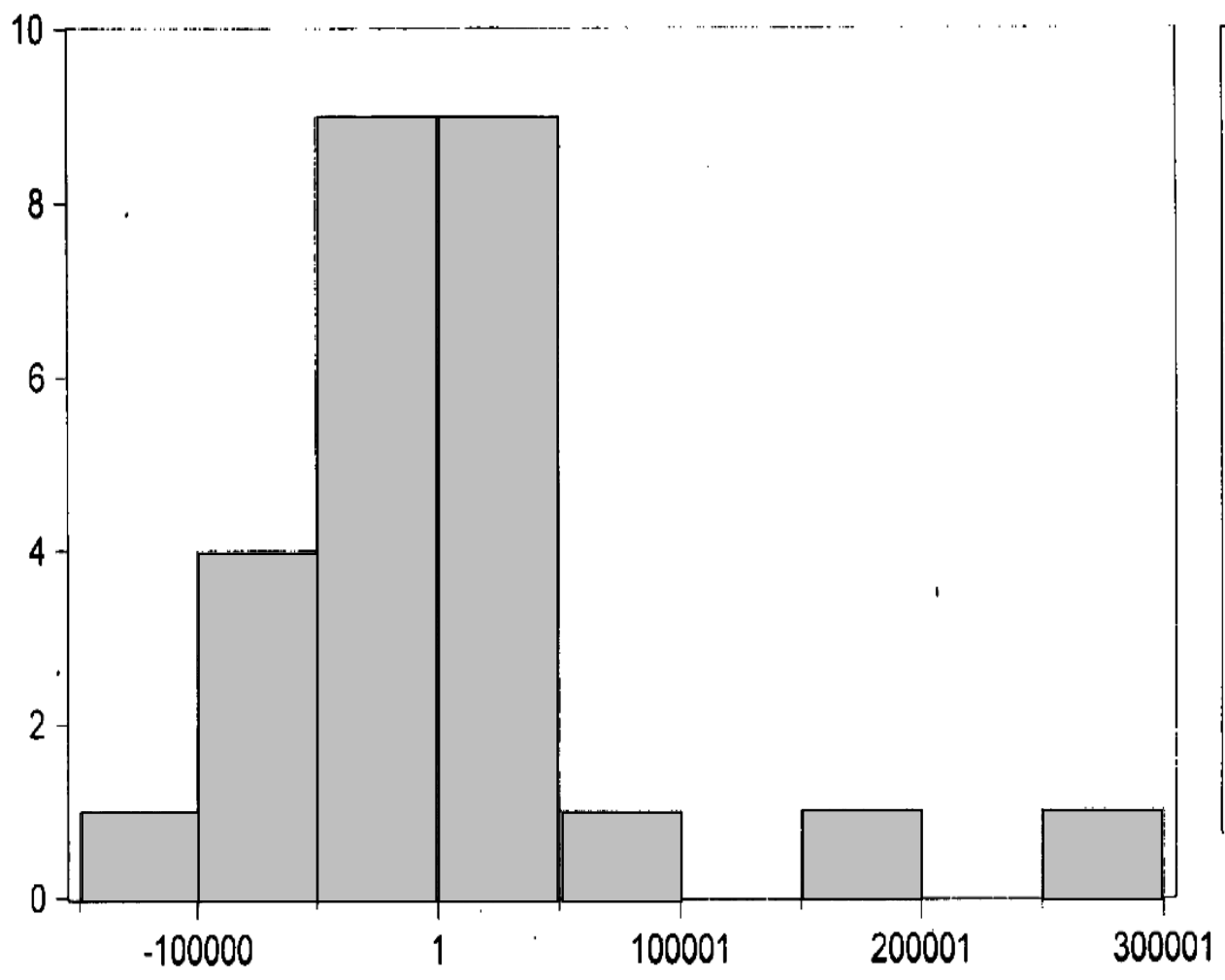

Series: Residuals

Sample 19902015

Observations 26

$\begin{array}{lr}\text { Mean } & 3.01 \mathrm{e}-11 \\ \text { Median } & -5350.334 \\ \text { Maximum } & 288495.9 \\ \text { Minimum } & -120984.8 \\ \text { Std. Dev. } & 81658.87 \\ \text { Skewness } & 1.953027 \\ \text { Kurtosis } & 7.887704 \\ & \\ \text { Jarque-Bera } & 42.40915 \\ \text { Probability } & 0.000000\end{array}$


Table 4.3

\begin{tabular}{|c|c|c|c|c|}
\hline $\begin{array}{l}\text { Heteroskedasticity } \\
\text { Test }\end{array}$ & Breusch-Pag & an-Godfrey & & \\
\hline F-statistic & 0153966 & Prob. & & 0.9994 \\
\hline $\begin{array}{l}\text { Obs*R-squared } \\
\text { Scaled explained SS }\end{array}$ & $\begin{array}{l}5.587302 \\
2.305605\end{array}$ & $\begin{array}{l}\text { Prob Chi-Squ } \\
\text { Prob. Chi-Sqi }\end{array}$ & $\begin{array}{l}\operatorname{lare}(16) \\
\operatorname{are}(16)\end{array}$ & $\begin{array}{l}0.9920 \\
1.0000\end{array}$ \\
\hline $\begin{array}{l}\text { Test Equation. } \\
\text { Dependent Variable: } \\
\text { Method:Least Squar } \\
\text { Date: 08/04/16 Tin } \\
\text { Sample: } 19902015 \\
\text { Included } \\
\text { observations: }\end{array}$ & $\begin{array}{l}D^{\wedge} 2 \\
4: 01\end{array}$ & & & \\
\hline Variable & Coefficient & Std Error & $\mathrm{t}-$ & Prob \\
\hline $\mathrm{c}$ & $9.28 \mathrm{E}+09$ & $9.78 \mathrm{E}+09$ & Statistic & 0.3674 \\
\hline $\begin{array}{l}\text { PBT(-1) } \\
\text { PBT(-2) } \\
\text { PBT(-3) } \\
\text { PBT(-4) } \\
\text { FPI(-1) } \\
\text { FPI(-2) } \\
\text { FPI(-3) } \\
\text { FPI(-4) } \\
\text { FTR(-1) } \\
\text { FTR(-2) } \\
\text { FTR(-3) } \\
\text { FT.R.(-4) } \\
\text { FXR(-1) } \\
\text { FXR(-2) } \\
\text { FXR(-3) } \\
\text { FXR(-4) }\end{array}$ & $\begin{array}{c}19223.93 \\
4973457 \\
66309.31 \\
123666.2 \\
-8613293 \\
8264.160 \\
10251.34 \\
17274.67 \\
-4282722 \\
3915723 \\
5169.633 \\
-19815.65 \\
-93330723 \\
-55405749 \\
-2.41 \mathrm{E}+08 \\
1.41 \mathrm{E}+08\end{array}$ & $\begin{array}{l}55890.05 \\
123878.9 \\
189450.8 \\
2756315 \\
13009.63 \\
2458102 \\
30423.08 \\
20332.33 \\
9750694 \\
1302650 \\
24068.32 \\
47955.78 \\
4.33 \mathrm{E}+08 \\
5.91 \mathrm{E}+08 \\
7.61 \mathrm{E}+08 \\
6.56 \mathrm{E}+08\end{array}$ & $\begin{array}{l}0.343960 \\
0.401477 \\
0.350008 \\
0448665 \\
-0662071 \\
0.336201 \\
0.336959 \\
0849616 \\
-0439222 \\
0300597 \\
0214790 \\
- \\
- \\
- \\
-0316975 \\
0215540\end{array}$ & $\begin{array}{l}0.7388 \\
0.6974 \\
0.7344 \\
0.6643 \\
0.5245 \\
0.7444 \\
0.7439 \\
\\
0.6709 \\
0.7706 \\
0.8347 \\
\\
0.8342 \\
0.9274 \\
0.7585 \\
0.8342\end{array}$ \\
\hline R-squared & 0.214896 & Mean depend & ent var & $6.41 \quad E+$ \\
\hline $\begin{array}{l}\text { Adjusted R-squared } \\
\text { S E. of regression } \\
\text { Sum squared resid } \\
\text { Log likelihood } \\
\text { F-statistic } \\
\text { Prob(F-statistic) }\end{array}$ & $\begin{array}{r}-1180844 \\
2.53 \mathrm{E}+10 \\
5.78 \mathrm{E}+21 \\
-645.9499 \\
0153966 \\
0999366\end{array}$ & $\begin{array}{l}\text { S.D depender } \\
\text { Akaike info cl } \\
\text { Schwarz crite } \\
\text { Hannan-Quin } \\
\text { Durbin }\end{array}$ & $\begin{array}{l}\text { t var } \\
\text { iterion } \\
\text { rion } \\
\text { n criter. } \\
\text { n stat }\end{array}$ & $\begin{array}{r}1.72 \mathrm{E}+10 \\
50 . \\
51.81875 \\
51.23303 \\
2.351511\end{array}$ \\
\hline
\end{tabular}


Table 4.4 : Autoregressive Model

\begin{tabular}{|c|c|c|c|c|}
\hline \multicolumn{5}{|c|}{$\begin{array}{l}\text { Dependent Variable: PBT } \\
\text { Method: Least Squares } \\
\text { Date: 08/04/16 Time: } 13: 54 \\
\text { Sample (adjusted): } 19902015 \\
\text { Included observations: } 26 \text { after adjustments } \\
\text { PBT = C }(1)^{\star} \mathrm{PBT}(-1)+\mathrm{C}(2)^{\star} \mathrm{PBT}(-2)+\mathrm{C}(3)^{\star} \mathrm{PBT}(-3)+\mathrm{C}(4)^{\star} \mathrm{PBT}(-4)+\mathrm{C}(5) \\
\quad{ }^{\star} \mathrm{FPI}(-1)+\mathrm{C}(6)^{\star} \mathrm{FPI}(-2)+\mathrm{C}(7)^{\star} \mathrm{FPI}(-3)+\mathrm{C}(8)^{\star} \mathrm{FPI}(-4)+\mathrm{C}(9)^{\star} \mathrm{FTR}(-1)+ \\
\quad \mathrm{C}(10)^{\star} \mathrm{FTR}(-2)+\mathrm{C}(11)^{\star} \mathrm{FTR}(-3)+\mathrm{C}(12)^{\star} \mathrm{FTR}(-4)+\mathrm{C}(13)^{\star} \mathrm{FXR}(-1)+ \\
\mathrm{C}(14)^{\star} \mathrm{FXR}(-2)+\mathrm{C}(15)^{\star} \mathrm{FXR}(-3)+\mathrm{C}(16)^{\star} \mathrm{FXR}(-4)+\mathrm{C}(17)\end{array}$} \\
\hline & Coefficient & Std. Error & t-Statistic & Prob. \\
\hline$C(1)$ & -1.666221 & 0.300156 & -5.551183 & 0.0004 \\
\hline $\mathrm{C}(2)$ & -1.845704 & 0.665288 & -2.774294 & 0.0216 \\
\hline$C(3)$ & -2.144169 & 1.017440 & -2.107415 & 0.0643 \\
\hline$C(4)$ & -2.196867 & $1.48 Q 271$ & -1.484097 & 0.1719 \\
\hline$C(5)$ & -0.200635 & 0.069868 & -2.8 & 184 \\
\hline$C(6)$ & 0.100408 & 0.132012 & 596 & 0.4664 \\
\hline$C(7)$ & 0.147263 & 0.163386 & 1317 & 0.3909 \\
\hline$C(8)$ & -0.232238 & 0.109194 & -2.126839 & 0.0623 \\
\hline $\mathrm{C}(9)$ & 0.082495 & 0.052366 & 1.575357 & 0.1496 \\
\hline$C(10)$ & -0.015053 & 0.006996 & -2.151697 & 0.0599 \\
\hline$C(11)$. & -0.121865 & 0.129258 & -0 & 0.3704 \\
\hline$C(12)$ & -0.368039 & 0.257545 & 026 & 0.1868 \\
\hline$C(13)$ & 7000.026 & 2325.924 & 67 & 0.0147 \\
\hline$C(14)$ & -172.0422 & 3173.418 & -0.054214 & 0.9579 \\
\hline$C(15)$ & 3329.064 & 4088.838 & 0.814183 & 0.4366 \\
\hline$C(16)$ & 9080.399 & 3523.774 & 2.576896 & 0.0298 \\
\hline$C(17)$ & -15999.62 & 52524.48 & -0.304613 & 0.7676 \\
\hline R-s & 0.944858 & Mean depe & nt var & \\
\hline Adjusted R-squared & 0.846829 & S.D. depend & lent var & 347747.4 \\
\hline S.E. of regression & 136098.1 & Akaike info & criterion & 26.72696 \\
\hline Sum squared resid & $1.67 \mathrm{E}+11$ & Schwarz crit & erion & 27.54956 \\
\hline Log likelihood & -330.4505 & Hannan-Qui & nn criter. & 26.96384 \\
\hline $\begin{array}{l}\text { F-statistic } \\
\text { Prob(F-statistic) }\end{array}$ & 9.638516 & Durbin-Wats & son stat & 2.075837 \\
\hline Prod(r-statistic) & 0.00 & & & \\
\hline
\end{tabular}


Table 4.5

\begin{tabular}{|c|c|c|c|c|}
\hline \multicolumn{5}{|c|}{ Breusch-Godfrey Serial Correlation LM Test: } \\
\hline $\begin{array}{l}\text { F-statistic } \\
\text { Obs^R-squared }\end{array}$ & $\begin{array}{l}0.463946 \\
7.037907\end{array}$ & $\begin{array}{l}\text { Prob. } F(4,5) \\
\text { Prob. Chi-S }\end{array}$ & dare (4) & $\begin{array}{l}0.7616 \\
0.1339\end{array}$ \\
\hline $\begin{array}{l}\text { Test Equation: } \\
\text { Dependent Variable: } \\
\text { Method: Least Squa } \\
\text { Date: 08/04/16 Tim } \\
\text { Sample: } 19902015 \\
\text { Included observation } \\
\text { Presample missing }\end{array}$ & $\begin{array}{l}\text { SID } \\
4: 01 \\
6 \\
\text { lagged res }\end{array}$ & als set to & & \\
\hline Variable & Coefficient & Std. Error & t-Statistic & Prob. \\
\hline $\begin{array}{c}C(1) \\
C(2) \\
C(3) \\
C(4) \\
C(5) \\
C(6) \\
C(7) \\
C(8) \\
C(9) \\
C(10) \\
C(11) \\
C(12) \\
C(13) \\
C(14) \\
C(15) \\
C(16) \\
C(17) \\
\text { RESID }(-1) \\
\text { RESID }(-2) \\
\text { RESID }(-3) \\
\text { RESID(-4) }\end{array}$ & $\begin{array}{r}-1.090521 \\
-1.954893 \\
-2.880817 \\
-3.024982 \\
-0.330138 \\
-0.138730 \\
-0.143012 \\
-0.008215 \\
0.114678 \\
-0.011822 \\
0.436912 \\
-0.125205 \\
155.8304 \\
-10.62955 \\
10572.78 \\
6481.325 \\
-86906.45 \\
0.265444 \\
1.291446 \\
-0.452060 \\
-1.843791\end{array}$ & $\begin{array}{l}2.197159 \\
3.793030 \\
5.954542 \\
6.999010 \\
0.326302 \\
0.804556 \\
0.405795 \\
0.339363 \\
0.251496 \\
0.019720 \\
0.736226 \\
0.468520 \\
7095.116 \\
13367.21 \\
1227841 \\
21641.28 \\
176999.8 \\
1.618569 \\
1.558969 \\
1.821856 \\
2.833635\end{array}$ & $\begin{array}{r}-0.496332 \\
-0.515391 \\
-0.483802 \\
-0.432201 \\
-1.011756 \\
-0.172431 \\
-0.352424 \\
-0.024207 \\
0.455982 \\
-0.599509 \\
0.593448 \\
-0.267234 \\
0.021963 \\
-0.000795 \\
0.861087 \\
0.299489 \\
-0.490998 \\
0.163999 \\
0.828397 \\
-0.248131 \\
-0.650681\end{array}$ & $\begin{array}{l}0.6407 \\
0.6282 \\
0.6490 \\
0.6836 \\
0.3581 \\
0.8699 \\
0.7389 \\
0.9816 \\
0.6675 \\
0.5750 \\
0.5787 \\
0.8000 \\
0.9833 \\
0.9994 \\
0.4285 \\
0.7766 \\
0.6442 \\
0.8762 \\
0.4452 \\
0.8139 \\
0.5440\end{array}$ \\
\hline $\begin{array}{l}\text { R-squared } \\
\text { Adjusted R-squared } \\
\text { S.E. of regression } \\
\text { Sum squared resid } \\
\text { Log likelihood } \\
\text { F-statistic } \\
\text { Prob(F-statistic) }\end{array}$ & $\begin{array}{r}0.270689 \\
-2.646556 \\
155935.4 \\
1.22 E+11 \\
-326.3470 \\
0.092789 \\
0.999961\end{array}$ & $\begin{array}{l}\text { Mean deper } \\
\text { S.D. depeno } \\
\text { Akaike info } \\
\text { Schwarz crit } \\
\text { Hannan-Qui } \\
\text { Durbin-Wats }\end{array}$ & $\begin{array}{l}\text { ent var } \\
\text { nt var } \\
\text { iterion } \\
\text { rion } \\
\text { n criter. } \\
\text { n stat }\end{array}$ & $\begin{array}{l}3.01 E-11 \\
81658.87 \\
26.71900 \\
27.73515 \\
27.01161 \\
2.000503\end{array}$ \\
\hline
\end{tabular}


Variance Decomposition of PBT:

Period S.E. PBT FPI FTR FXR

\begin{tabular}{|rlllll|}
\hline 1 & 136098.1 & 100.0000 & 0.000000 & 0.000000 & 0.000000 \\
2 & 167368.3 & 80.35840 & 3.460404 & 8.068730 & 8.112468 \\
3 & 191957.9 & 62.90096 & 19.44572 & 11.03610 & 6.617223 \\
4 & 316909.8 & 23.86963 & 52.22633 & 19.43714 & 4.466903 \\
5 & 404476.5 & 22.87481 & 50.57304 & 22.14290 & 4.409246 \\
6 & 414729.7 & 23.08871 & 51.37516 & 21.12033 & 4.415807 \\
7 & 565830.3 & 54.27546 & 27.74345 & 11.75624 & 6.224844 \\
8 & 2329059 & 79.54818 & 14.25958 & 5.639893 & 0.552342 \\
9 & 2901014 & 61.39330 & 23.69140 & 7.300855 & 7.614445 \\
10 & 3492869 & 42.35190 & 32.36704 & 17.86425 & 7.416812 \\
\hline
\end{tabular}

